\title{
SIMULATION STUDY OF THE SHORT BARREL OF THE GUN MANUFACTURE
}

\author{
Bronislav Chramcov \\ Ladislav Daníček \\ Tomas Bata University in Zlín \\ Faculty of Applied Informatics \\ Nad Stráněmi 4511, 76005 Zlín, Czech Republic \\ E-mail: chramcov@fai.utb.cz
}

\section{KEYWORDS}

Discrete event systems modelling and simulation, simulation of manufacturing, Witness.

\begin{abstract}
This paper deals with the use of computer simulation aiming at more efficient production of the manufacturing system. In our case, the possibilities of use are demonstrated on a particular example from industrial practice. The purpose was to build up a model of the existing short barrel of the gun manufacturing line, and, especially, to propose a solution for increase of productivity, and to find bottlenecks of the system. The Witness simulation environment was used for modelling and subsequent simulation. On the basis of predefined requirements of the user, several simulation experiments were suggested. The results of these experiments have revealed non-economy and a very small passage ability of the existing system.
\end{abstract}

\section{INTRODUCTION}

The computer simulation of discrete events is becoming a necessary supporting instrument in making the operation of production systems more effective. Among other things, this is due to its capability of simulating and following up both stochastic and dynamic properties of individual processes, and thus predicting their behaviour.

In the present so-called turbulent environment, any effective operation of the production systems cannot be achieved any more only by local optimization of individual parameters or subsystems. These are so interacting that it is not possible to solve them separately, and the whole system has to be considered globally, and the optimum of the system as a whole must be searched for. High dynamics, complexity and, as such, also insecurity at the solution of company tasks require more and more the use of such methods and such supporting means that allow a complex access to the design of production systems, as well as fast tests of a variety of different variants of the solution, and thus minimization of a risk of erroneous decisions. Therefore, a significant help is a complex dynamic analysis of the production systems by means of computer simulation. So, at the present time, the computer simulation is a necessary part of every large production process. With its help you can perform the simulation of real environment. If the process has been modelled correctly, the production simulation can be made for a few days or weeks in advance. This instrument gives the companies the possibility of operational planning at minimizing energies, inventories and labour.

This paper deals with the simulation study of a particular manufacturing line, in our case this is the short barrel of the gun manufacturing line in a company producing the guns. The production process is described in detail in Section 2. This study includes an analysis of the current status of the plant, data collection, construction and verification of the model, and, in particular, a proposal and implementation of simulation experiments. The aim was to propose a solution for increase of productivity and to find bottlenecks of the manufacturing system. The simulation experiments were proposed on the basis of the predefined requirements of the user. The task was to determine an appropriate number of machines in individual workplaces, or, rather, to establish a correspondent number of shifts of the operation of these workplaces. The Witness simulation environment was used for the construction of the model and subsequent simulation. Basic information on this environment is to be found in Section 3. In this Section, the process of model creation in the Witness environment is outlined. Description of the proposed simulation experiments and evaluation of achieved results is presented in Section 4.

\section{DESCRIPTION OF THE SHORT BARREL OF THE GUN MANUFACTURE}

The machines used in the manufacture serve for machining the products in various production phases. These are, in particular, lathes, grinding and drilling machines. All these machines are machining only one product at a given moment. Thus, only one part enters the machine and a specific operation is carried out on it, and also only one part leaves the machine. Individual machines are arranged into groups. Each group forms a workplace to perform a certain operation. Every machine (except for one machine) is operated by one operator. For this reason, labour does not have to be considered in the model. Table 1 shows quantities of 
machines in individual workplaces which are used in the system for machining the products, together with the number of shifts during which the workplace is in operation.

Table 1: Number of machines in individual workplaces and number of shifts

\begin{tabular}{|r|l|c|c|}
\hline $\begin{array}{c}\text { Workplace } \\
\text { No. }\end{array}$ & Description of workplace & $\begin{array}{l}\text { Number of } \\
\text { machines }\end{array}$ & $\begin{array}{c}\text { Number } \\
\text { of shifts }\end{array}$ \\
\hline 1 & $\begin{array}{l}\text { Drilling of the short } \\
\text { barrel of the gun }\end{array}$ & 3 & 2 \\
\hline 2 & Drilling - countersinking & 1 & 2 \\
\hline 3 & Turning-Lathe - Fischer & 3 & 2 \\
\hline 4 & Turning-Lathe - SV 18 & 7 & 2 \\
\hline 5 & Turning-Lathe - Liberty & 6 & 2 \\
\hline 6 & Honing & 5 & 2 \\
\hline 7 & Forging & 2 & 3 \\
\hline 8 & Grinding & 6 & 2 \\
\hline 9 & $\begin{array}{l}\text { Turning-Lathe - } \\
\text { chambers }\end{array}$ & 3 & 2 \\
\hline 10 & Polishing - chambers & 2 & 2 \\
\hline 11 & Manual treatment & 9 & 1 \\
\hline
\end{tabular}

Each workplace performs a certain operation. The product comes through some workplaces repeatedly, therefore one workplace carries out a few different operations. The manufacturing process is described step by step below, in Table. 3. Here is given the number of the workplace where a particular operation is made, and the time of individual operations. This data was provided by the operator of the plant from its planning system where the data for all machines are stored. The data collection was carried out in that workplace for a long time, hence we can consider this data to be very correct. So any further measurement directly in operation would be just waste of time.

Products' handling in the production is made with the help of vehicles. Material handling is not controlled in real manufacture; this is done in case of emptying individual buffers. Time of material handling from one machine to another is minimal, as the distance is very short. Therefore we can say that the time of material handling is negligible.

The manufacturing plant works in three-shift operation. Most workplaces are in two-shift operation, though (see Table 1). Overview of individual working shifts of the manufacturing system is shown in Tab. 2.

Table 2: Working shifts of the department of short barrel of the gun

\begin{tabular}{|l|c|c|c|}
\hline \multicolumn{1}{|c|}{ Shift } & $\begin{array}{c}\text { Shift } \\
\text { start }\end{array}$ & Break & $\begin{array}{c}\text { Shift } \\
\text { end }\end{array}$ \\
\hline Morning shift & $5: 45$ & $10: 30-11: 00$ & $14: 15$ \\
\hline Afternoon shift & $14: 00$ & $17: 30-18: 00$ & $22: 00$ \\
\hline Night shift & $22: 00$ & $2: 00-2: 30$ & $6: 00$ \\
\hline
\end{tabular}

In operation, maintenance of the machine is done on a regular basis. Thanks to this maintenance, faults occur on individual machines only exceptionally. Time of maintenance together with elimination of faults will take $3 \%$ of machine time.

Table 3: Manufacturing procedure of the short barrel of the gun

\begin{tabular}{|c|c|c|c|}
\hline \begin{tabular}{|c|} 
Operation \\
No.
\end{tabular} & Description of operation & $\begin{array}{c}\text { Workplace } \\
\text { No. }\end{array}$ & $\begin{array}{l}\text { Process } \\
\text { Time }[\mathrm{s}]\end{array}$ \\
\hline 1. & $\begin{array}{l}\text { Hole drilling for preparation of a } \\
\text { bore }\end{array}$ & 1 & 17,4 \\
\hline 2. & $\begin{array}{l}\text { Countersink of ends at the bored } \\
\text { hole }\end{array}$ & 2 & 7,8 \\
\hline 3. & $\begin{array}{l}\text { Turning of the recess on one side of } \\
\text { the cut for clamping onto the } \\
\text { copying machine }\end{array}$ & 3 & 14,4 \\
\hline 4. & $\begin{array}{l}\text { Turning of surface either for cone or } \\
\text { cylinder shape according to the type } \\
\text { of the forging, or final shape of the } \\
\text { short barrel of the gun, respectively }\end{array}$ & 4 & 13,8 \\
\hline 5. & $\begin{array}{l}\text { Execution of ends is done for } \\
\text { clamping for the forging and honing } \\
\text { operations that follow }\end{array}$ & 5 & 10,2 \\
\hline 6. & $\begin{array}{l}\text { Honing. This is final treatment of the } \\
\text { hole before the very forging. } \\
\text { Honing is done to achieve necessary } \\
\text { hole size and roughness }\end{array}$ & 6 & 40,2 \\
\hline 7. & $\begin{array}{l}\text { Forging is carrying out the final } \\
\text { sizes of the bore and surface of the } \\
\text { forged piece as per the calibre } \\
\text { required and type of the short barrel } \\
\text { of the gun }\end{array}$ & 7 & 49,2 \\
\hline 8. & $\begin{array}{l}\text { Cutting-off and planing the face of } \\
\text { the short barrel of the gun to the } \\
\text { length required acc. to the type - the } \\
\text { so-called first face }\end{array}$ & 4 & 10,2 \\
\hline 9. & $\begin{array}{l}\text { Turning operation of turning of the } \\
\text { faces and recess }\end{array}$ & 3 & 22,8 \\
\hline 10. & $\begin{array}{l}\text { Again, cutting off, countersinking, } \\
\text { milling of the shape in the area of } \\
\text { the cartridge chamber, turning of the } \\
\text { diameter of the short barrel of the } \\
\text { gun plus addition under the grinder }\end{array}$ & 4 & 155,4 \\
\hline 11. & $\begin{array}{l}\text { Grinding of the diameter of the } \\
\text { short barrel of the gun to the final } \\
\text { size, shape and machining }\end{array}$ & 8 & 94,8 \\
\hline 12. & $\begin{array}{l}\text { Turning with connection to the } \\
\text { subtoothing and the very turning of } \\
\text { the toothing }\end{array}$ & 5 & 84 \\
\hline 13. & $\begin{array}{l}\text { Turning of the cartridge chamber } \\
\text { and turning of the muzzle, where its } \\
\text { final length is determined acc. to } \\
\text { individual types }\end{array}$ & 9 & 91,2 \\
\hline 14. & $\begin{array}{l}\text { Polishing the chute and polishing the } \\
\text { cartridge chamber }\end{array}$ & 10 & 28,2 \\
\hline 15. & $\begin{array}{l}\text { Checking and preparatory activities } \\
\text { for the next work with the product, } \\
\text { such as size check, cleaning the } \\
\text { conservation coat, degreasing, etc. }\end{array}$ & 11 & 1,8 \\
\hline
\end{tabular}

The simplified scheme of the operation of the production plant is presented in Figure 1. 


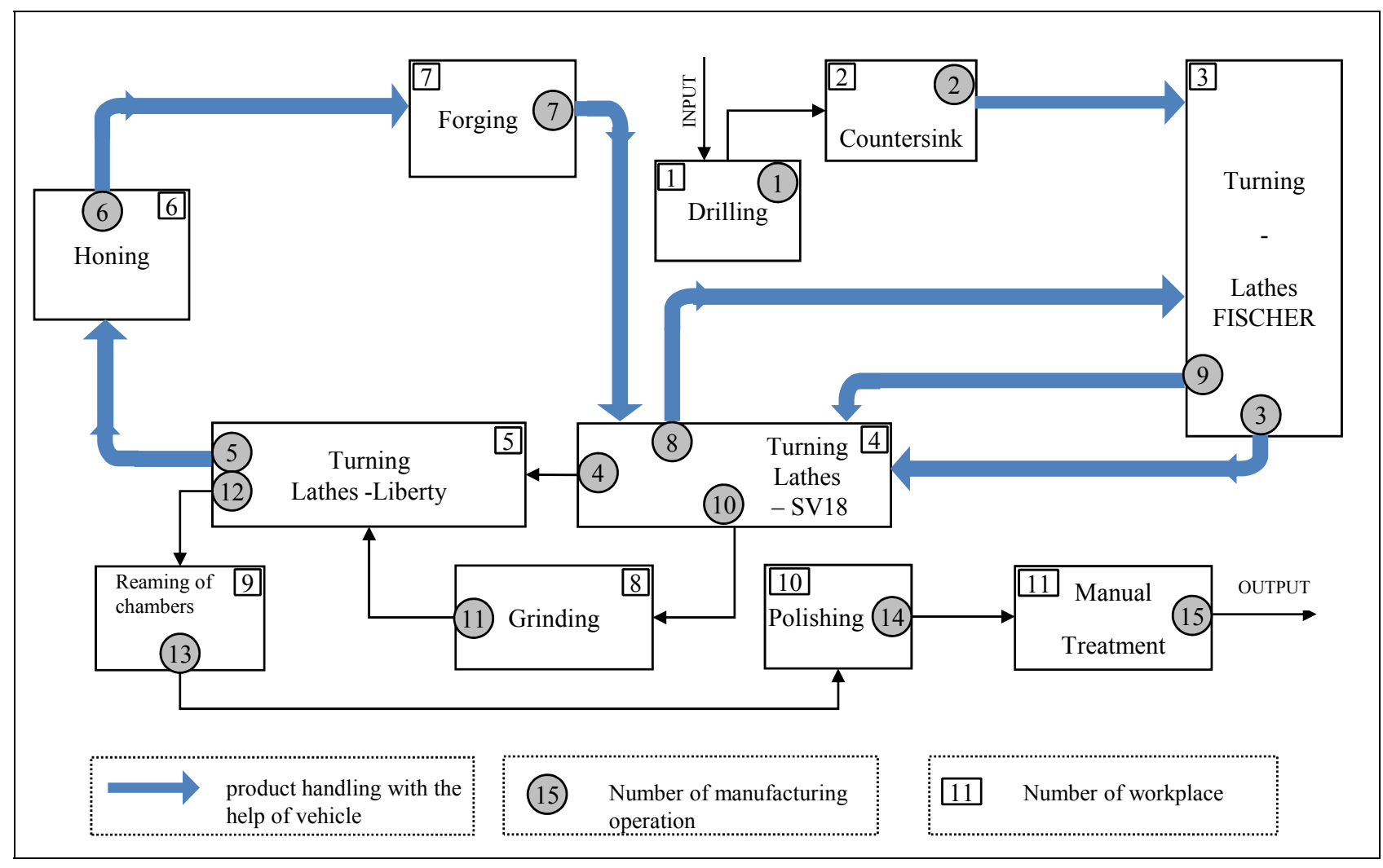

Figure 1: Simplified scheme of the operation of the production plant

\section{MODEL CONSTRUCTION IN WITNESS SIMULATION ENVIRONMENT}

For building up the model and subsequent implementation of the proposed experiments, it is possible to use a wide range of simulation programs and systems (Banks 2005). The Witness system environment was available in this case. This system is offered by the Lanner Group and it contains many elements for discrete-part manufacturing. Witness models are based on template elements. These may be customized and combined into module elements and templates for reuse. The standard machine elements can be single, batch, production, assembly, multistation or multicycle. Other discrete modelling elements include multiple types of conveyor, tracks, vehicles, labor and carriers. The behavior of each element is described on a tabbed detail form in the Witness user interface. The models are displayed in a 2-D layout animation with multiple windows and display layers.

Every operating workplace of the manufacturing line is modelled in the Witness environment with help of the element Machine of Single type. Parameters of each element are set by means of tabbed detail form. Quantity of machines in the particular workplace and cycle time are set up according to Table 1 and Table 2 . If a workplace carries out a few operations with a different cycle time, this parameter is considered as a variable. The value of this variable is then set up in the output rule of the buffer in front of the workplace concerned.

Products' handling in the manufacture is performed by vehicles. These are modelled with help of the element Vehicle. These vehicles move along the predefined tracks (modelled by means of the element Track). In the simulation model, the handling is carried out at the moment when quantity of products in the buffer has decreased under a value of 3. Capacity of each buffer is 5000. As mentioned above, time of material handling from one machine to another is minimal.

For creating the model of process of maintenance and fault in individual workplaces, an auxiliary element of Machine type is used, which takes care of fault generation (maintenance on individual machines of the particular workplace). Thus, each workplace has its fault generator. This solution is given by the fact that it is not possible to set up a fault only on one machine of the particular workplace which is just modelled by the only element. A fault (or maintenance, respectively) is generated by means of a new part (element of Part type), which at the input into the particular fault generator will cause a fault on the corresponding machine of that workplace. Time of fault (maintenance) is set up by means of the parameter Cycle Time of the fault generator. For generating a fault (maintenance), normal distribution is used. The parameters are chosen so that a fault (maintenance) occurs on each machine at least once a day. 
In the model, working shifts are made with help of the element Shift. For purposes of the simulation, three oneweek shifts were created on the basis of Table 2 . The shifts were then assigned to the individual workplaces as per the number of shifts in which the particular workplace is in operation every day.

\section{SIMULATION EXPERIMENTS AND RESULTS}

After building up the model of the manufacturing line, the proposed model must be first verified. The verified model will be subsequently used for simulation experiments. As the system in view works in continuous operation, the model would have to be first filled with products in order to verify the model with the real system. This can be made in the Witness environment due to the parameter WarmUp Period. The value of this parameter determines the time when the followed-up statistics and variables are zeroized. The value WarmUp Period is set up to 172800 seconds, which corresponds to the time of 2 days. This time is sufficient for filling the whole model with products. Total time of simulation is 2 weeks (that means 2 days Warm Up, 12 days testing period). The Tables given below show the results of individual simulation experiments.

\section{Simulation of the current status and verification of the model}

One of the most important and difficult tasks facing a model developer is the verification and validation of the simulation model. There is a great number of verification, validation and testing techniques. It is possible to classify these techniques into four primary categories: informal, static, dynamic and formal (Banks 1998). From the point of view of this terminology, only informal and static techniques were used. During the verification, especially percentage capacity utilization of individual workplaces and total production of the manufacturing line were monitored (see Table 4). The values of monitored characteristics are comparable to those of the real system. The Table 4 shows ineffective operation of this manufacturing system. More than half of workplaces are blocked. It is caused due to filling the buffers between individual workplaces (capacity of buffers is 5000). Busy time of most workplaces is less than $50 \%$. Workplace of Honing is the critical point of system (busy time practically 100\%, 3\% maintenance).

\section{Proposal of model parameters changes resulting in increase in production efficiency}

The simulation experiments were suggested on the basis of the predefined requirements of the user:

- $\quad$ It is possible to reduce the number of machines in individual workplaces

- It is not possible to increase the number of machines in a workplace

- It is possible to change the number of working shifts of individual workplaces
The task was thus to determine an adequate number of machines in individual workplaces, or possibly, to set up an appropriate number of working shifts of the operation of these workplaces.

Numbers of modifications were gradually proposed for the present status of the manufacturing line. All the proposed experiments were simulated. Description and results of some experiments are presented below.

Tab 4: Report on results of current manufacturing line

\begin{tabular}{|c|c|c|c|c|c|}
\hline \multicolumn{6}{|c|}{ Report on individual workplaces } \\
\hline $\begin{array}{c}\text { Workplace } \\
\text { No. }\end{array}$ & $\begin{array}{l}\text { Description of } \\
\text { workplace }\end{array}$ & $\begin{array}{c}\text { Number } \\
\text { of } \\
\text { machines }\end{array}$ & $\begin{array}{c}\text { Number } \\
\text { of } \\
\text { shifts } \\
\end{array}$ & $\begin{array}{c}\text { Busy } \\
\text { Time } \\
{[\%]} \\
\end{array}$ & $\begin{array}{c}\text { Blocked } \\
\text { Time } \\
{[\%]}\end{array}$ \\
\hline 1 & Drilling & 3 & 2 & 35,10 & 61,87 \\
\hline 2 & Countersinking & 1 & 2 & 46,73 & 50,13 \\
\hline 3 & $\begin{array}{l}\text { Turning-Lathe } \\
\text { - Fischer }\end{array}$ & 3 & 2 & 34,94 & 60,39 \\
\hline 4 & $\begin{array}{c}\text { Turning-Lathe } \\
\text { - SV } 18\end{array}$ & 7 & 2 & 43,58 & 53,43 \\
\hline 5 & $\begin{array}{l}\text { Turning-Lathe } \\
\text { - Liberty }\end{array}$ & 6 & 2 & 30,15 & 57,14 \\
\hline 6 & Honing & 2 & 2 & 96,95 & 0,00 \\
\hline 7 & Forging & 2 & 3 & 66,38 & 16,74 \\
\hline 8 & Grinding & 6 & 2 & 23,00 & 0,00 \\
\hline 9 & $\begin{array}{l}\text { Turning-Lathe } \\
\text { - chambers }\end{array}$ & 3 & 2 & 47,49 & 0,00 \\
\hline 10 & $\begin{array}{l}\text { Polishing - } \\
\text { chambers }\end{array}$ & 2 & 2 & 22,02 & 0,00 \\
\hline 11 & $\begin{array}{c}\text { Manual } \\
\text { treatment }\end{array}$ & 9 & 1 & 0,54 & 0,00 \\
\hline \multicolumn{2}{|c|}{ TOTAL } & 44 & 22 & 40,63 & 27,25 \\
\hline \multicolumn{4}{|c|}{ Number of necessary labour per day } & \multicolumn{2}{|c|}{81} \\
\hline \multicolumn{4}{|c|}{ Total production of manufacture [pieces] } & \multicolumn{2}{|c|}{6230} \\
\hline
\end{tabular}

\section{Experiment No.1}

Experiment No.1 eliminates the significant bottleneck of current manufacturing system by means of increasing the number of working shifts. Operation time of workplace Honing was set to three shift operation. Due to high manufacturing capacity of machines before workplace Honing and inadequate capacity of Honing many workplaces became blocked. Blocked Time of these workplaces can be reduced with cut in manufacturing capacity of workplaces Drilling and Countersinking. Further the unsuitable number of working place of Manual treatment is reduced. Results of this simulation experiment are shown in Table 5. Proposed changes are highlighted. Original values are stated in the brackets.

More than double Total production increase and labour cuts (11 labourers) are reached in this experiment. Disadvantage of this experiment consists in partial blocking the Turning-Lathes - Fischer resulting from maximum busy time of Turning-Lathes - SV18. The experiment No.2 solves this problem. 
Tab 5: Report on Results of experiment No.1

\begin{tabular}{|c|c|c|c|c|c|}
\hline \multicolumn{6}{|c|}{ Report on individual workplaces } \\
\hline $\begin{array}{c}\text { Workplace } \\
\text { No. }\end{array}$ & $\begin{array}{l}\text { Description of } \\
\text { workplace }\end{array}$ & $\begin{array}{c}\text { Number } \\
\text { of } \\
\text { machines }\end{array}$ & $\begin{array}{c}\text { Number } \\
\text { of } \\
\text { shifts } \\
\end{array}$ & $\begin{array}{c}\text { Busy } \\
\text { Time } \\
{[\%]}\end{array}$ & $\begin{array}{c}\text { Blocked } \\
\text { Time } \\
{[\%]}\end{array}$ \\
\hline 1 & Drilling & $2(3)$ & $1(2)$ & 96,99 & 0,00 \\
\hline 2 & Countersinking & 1 & $1(2)$ & 86,95 & 0,00 \\
\hline 3 & $\begin{array}{l}\text { Turning-Lathe } \\
\text { - Fischer }\end{array}$ & 3 & 2 & 60,04 & 18,41 \\
\hline 4 & $\begin{array}{c}\text { Turning-Lathe } \\
\text { - SV } 18\end{array}$ & 7 & 2 & 97,01 & 0,00 \\
\hline 5 & $\begin{array}{l}\text { Turning-Lathe } \\
\text { - Liberty }\end{array}$ & 6 & 2 & 59,03 & 0,00 \\
\hline 6 & Honing & 2 & $3(2)$ & 73,17 & 0,00 \\
\hline 7 & Forging & 2 & 3 & 90,85 & 0,00 \\
\hline 8 & Grinding & 6 & 2 & 56,69 & 0,00 \\
\hline 9 & $\begin{array}{l}\text { Turning-Lathe } \\
\text { - chambers }\end{array}$ & 3 & 2 & 97,03 & 0,00 \\
\hline 10 & $\begin{array}{c}\text { Polishing - } \\
\text { chambers }\end{array}$ & 2 & 2 & 45,01 & 0,00 \\
\hline 11 & $\begin{array}{l}\text { Manual } \\
\text { treatment }\end{array}$ & $1(9)$ & 1 & 10,95 & 0,00 \\
\hline \multicolumn{2}{|l|}{ TOTAL } & $35(44)$ & $21(22)$ & $\begin{array}{c}70,34 \\
(40,63)\end{array}$ & $\begin{array}{c}1,67 \\
(27,25)\end{array}$ \\
\hline \multicolumn{4}{|c|}{ Number of necessary labour per day } & \multicolumn{2}{|c|}{$70(81)$} \\
\hline \multicolumn{4}{|c|}{ Total production of manufacture [pieces] } & \multicolumn{2}{|c|}{$14019(6230)$} \\
\hline
\end{tabular}

Tab 6: Report on Results of experiment No.2

\begin{tabular}{|c|c|c|c|c|c|}
\hline \multicolumn{6}{|c|}{ Report on individual workplaces } \\
\hline $\begin{array}{c}\text { Workplace } \\
\text { No. }\end{array}$ & $\begin{array}{l}\text { Description of } \\
\text { workplace }\end{array}$ & $\begin{array}{c}\text { Number } \\
\text { of } \\
\text { machines }\end{array}$ & $\begin{array}{c}\text { Number } \\
\text { of } \\
\text { shifts } \\
\end{array}$ & $\begin{array}{c}\text { Busy } \\
\text { Time } \\
{[\%]}\end{array}$ & $\begin{array}{c}\text { Blocked } \\
\text { Time } \\
{[\%]}\end{array}$ \\
\hline 1 & Drilling & $2(3)$ & $1(2)$ & 96,99 & 0,00 \\
\hline 2 & Countersinking & 1 & $1(2)$ & 86,95 & 0,00 \\
\hline 3 & $\begin{array}{l}\text { Turning-Lathe } \\
\text { - Fischer }\end{array}$ & 3 & 2 & 67,55 & 0,00 \\
\hline 4 & $\begin{array}{c}\text { Turning-Lathe } \\
\text { - SV } 18\end{array}$ & 7 & $3(2)$ & 93,07 & 0,00 \\
\hline 5 & $\begin{array}{l}\text { Turning-Lathe } \\
\text { - Liberty }\end{array}$ & 6 & 2 & 84,60 & 0,00 \\
\hline 6 & Honing & 2 & $3(2)$ & 76,17 & 0,00 \\
\hline 7 & Forging & 2 & 3 & 93,40 & 0,00 \\
\hline 8 & Grinding & 6 & 2 & 84,99 & 0,00 \\
\hline 9 & $\begin{array}{l}\text { Turning-Lathe } \\
\text { - chambers }\end{array}$ & 3 & $3(2)$ & 94,49 & 0,00 \\
\hline 10 & $\begin{array}{l}\text { Polishing - } \\
\text { chambers }\end{array}$ & 2 & 2 & 64,66 & 0,00 \\
\hline 11 & $\begin{array}{l}\text { Manual } \\
\text { treatment }\end{array}$ & $1(9)$ & 1 & 15,73 & 0,00 \\
\hline \multicolumn{2}{|c|}{ TOTAL } & $35(44)$ & $23(22)$ & $\begin{array}{c}78,05 \\
(40,63)\end{array}$ & $\begin{array}{c}0,00 \\
(27,25)\end{array}$ \\
\hline \multicolumn{4}{|c|}{ Number of necessary labour per day } & \multicolumn{2}{|c|}{$80(81)$} \\
\hline \multicolumn{4}{|c|}{ Total production of manufacture [pieces] } & \multicolumn{2}{|c|}{$20140(6230)$} \\
\hline
\end{tabular}

\section{Experiment No.2}

Experiment No.2 tries to remedy the critical points of the previous experiment. Results in Table 5 show that it is necessary to increase manufacturing capacity of Turning-Lathes-SV18 and Turning-Lathes - chambers. Solution to this problem is setting the working shifts of these workplaces in three-shift operation. Results of this simulation experiment are shown in Table 6.

More than treble Total production increase at the practically identical labour (80 labourers) is reached in this experiment. Blockage of the machine almost never occurs. Imperceptible blocking of the Turning-LathesLiberty comes about after one month simulation.

\section{Experiment No.3}

Experiment No.3 solves lower workload of TurningLathes - Liberty, workplace of grinding and workplace of Polishing-chambers. The number of Turning-LathesLiberty and grinding machines is decreased. The workplace of polishing-chambers is set in three-shift operation but the number of machines is reduced.

Results of this simulation experiment are shown in Table 7. Five labour positions are saved compared to the previous experiment. Value of Total production is practically unchanged. Imperceptible blocking of the Turning-Lathe-Liberty comes about after two month simulation.

Tab 7: Report on Results of experiment No.3

\begin{tabular}{|c|c|c|c|c|c|}
\hline \multicolumn{6}{|c|}{ Report on individual workplaces } \\
\hline $\begin{array}{c}\text { Workplace } \\
\text { No. }\end{array}$ & $\begin{array}{l}\text { Description of } \\
\text { workplace }\end{array}$ & \begin{tabular}{c|}
$\begin{array}{c}\text { Number } \\
\text { of } \\
\text { machines }\end{array}$ \\
\end{tabular} & $\begin{array}{c}\text { Number } \\
\text { of } \\
\text { shifts }\end{array}$ & $\begin{array}{c}\text { Busy } \\
\text { Time } \\
{[\%]} \\
\end{array}$ & $\begin{array}{c}\text { Blocked } \\
\text { Time } \\
{[\%]} \\
\end{array}$ \\
\hline 1 & Drilling & $2(3)$ & $1(2)$ & 96,99 & 0,00 \\
\hline 2 & Countersinking & 1 & $1(2)$ & 86,95 & 0,00 \\
\hline 3 & $\begin{array}{l}\text { Turning-Lathe } \\
\text { - Fischer }\end{array}$ & 3 & 2 & 66,83 & 0,00 \\
\hline 4 & $\begin{array}{c}\text { Turning-Lathe } \\
\text { - SV } 18\end{array}$ & 7 & $3(2)$ & 90,89 & 0,00 \\
\hline 5 & $\begin{array}{l}\text { Turning-Lathe } \\
\text { - Liberty }\end{array}$ & $5(6)$ & 2 & 95,20 & 0,00 \\
\hline 6 & Honing & 2 & $3(2)$ & 75,93 & 0,00 \\
\hline 7 & Forging & 2 & 3 & 91,80 & 0,00 \\
\hline 8 & Grinding & $5(6)$ & 2 & 95,54 & 0,00 \\
\hline 9 & $\begin{array}{l}\text { Turning-Lathe } \\
\text { - chambers }\end{array}$ & 3 & $3(2)$ & 94,51 & 0,00 \\
\hline 10 & $\begin{array}{l}\text { Polishing - } \\
\text { chambers }\end{array}$ & $1(2)$ & $3(2)$ & 87,61 & 0,00 \\
\hline 11 & $\begin{array}{c}\text { Manual } \\
\text { treatment }\end{array}$ & $1(9)$ & 1 & 15,74 & 0,00 \\
\hline \multicolumn{2}{|c|}{ TOTAL } & $32(44)$ & $24(22)$ & $\begin{array}{c}81,64 \\
(40,63)\end{array}$ & $\begin{array}{c}0,00 \\
(27,25)\end{array}$ \\
\hline \multicolumn{4}{|c|}{ Number of necessary labour per day } & \multicolumn{2}{|c|}{$75(81)$} \\
\hline \multicolumn{4}{|c|}{ Total production of manufacture [pieces] } & \multicolumn{2}{|c|}{$20146(6230)$} \\
\hline
\end{tabular}




\section{Experiment No.4}

Experiment No.4 corresponds practically to experiment No.3. This experiment corrects the lower workload of Turning-Lathes - Fischer. The number of machines in this workplace is reduced. Results of this simulation experiment are shown in Table 8.

Total production increase (cca 120 pieces) and labour cut (1 labourer) are achieved compared to experiment No.3. However Turning-Lathes-SV18 are blocked soon (after 3 weeks). It is resulted from maximum busy time of Turning-Lathes-Fischer.

Tab 8: Report on Results of experiment No.4

\begin{tabular}{|c|c|c|c|c|c|}
\hline \multicolumn{7}{|c|}{ Report on individual workplaces } \\
\hline $\begin{array}{c}\text { Workplace } \\
\text { No. }\end{array}$ & $\begin{array}{c}\text { Description of } \\
\text { workplace }\end{array}$ & $\begin{array}{c}\text { Number } \\
\text { of } \\
\text { machines }\end{array}$ & $\begin{array}{c}\text { Number } \\
\text { of } \\
\text { shifts }\end{array}$ & $\begin{array}{c}\text { Busy } \\
\text { Time } \\
{[\%]}\end{array}$ & $\begin{array}{c}\text { Blocked } \\
\text { Time } \\
{[\%]}\end{array}$ \\
\hline 1 & Drilling & $2(3)$ & $1(2)$ & 96,99 & 0,00 \\
\hline 2 & Countersinking & 1 & $1(2)$ & 86,95 & 0,00 \\
\hline 3 & $\begin{array}{c}\text { Turning-Lathe } \\
- \text { Fischer }\end{array}$ & $2(3)$ & 2 & 97,00 & 0,00 \\
\hline 4 & $\begin{array}{c}\text { Turning-Lathe } \\
\text { - SV 18 }\end{array}$ & 7 & $3(2)$ & 89,38 & 0,00 \\
\hline 5 & $\begin{array}{c}\text { Turning-Lathe } \\
\text { - Liberty }\end{array}$ & $5(6)$ & 2 & 95,87 & 0,00 \\
\hline 6 & Honing & 2 & $3(2)$ & 79,18 & 0,00 \\
\hline 7 & Forging & 2 & 3 & 95,87 & 0,00 \\
\hline 8 & Grinding & $5(6)$ & 2 & 95,61 & 0,00 \\
\hline 9 & $\begin{array}{c}\text { Turning-Lathe } \\
- \text { chambers }\end{array}$ & 3 & $3(2)$ & 95,05 & 0,00 \\
\hline 10 & $\begin{array}{c}\text { Polishing - } \\
\text { chambers }\end{array}$ & 2 & 2 & 65,05 & 0,00 \\
\hline 11 & $\begin{array}{c}\text { Manual } \\
\text { treatment }\end{array}$ & $1(9)$ & 1 & 15,83 & 0,00 \\
\hline TOTAL & $32(44)$ & $23(22)$ & 82,98 & 0,00 \\
\hline Number of necessary labour per day & & $74(27,25)$ \\
\hline Total production of manufacture [pieces] & $20263(6230)$ \\
\hline
\end{tabular}

\section{Experiments Evaluation}

On the basis of the results of executed experiments (see Table 5, 6, 7, 8); we can say that Experiment No.4 is the best. Total production of manufacture is the highest and labour cuts (7 labourers) are achieved. However this experiment has a weak point which comes out after longer simulation time. Turning-Lathes-SV18 are blocked after 3 weeks. It is resulted from maximum busy time of Turning-Lathes-Fischer. From this point of view it is better Experiment No.3. Blockage of the machines almost never occurs. Imperceptible blocking of the Turning-Lathe-Liberty comes about not until after two month simulation time. Six labour positions are saved compared to the current manufacturing line. Value of Total production is practically comparable to Experiment No.4.

\section{CONCLUSION}

This paper presents possibilities of utilization of dynamic simulation when searching for reserves of the manufacturing systems. On a concrete example, utilization of the simulation Witness environment is demonstrated in the suggestions for increase of production efficiency in the company manufacturing the short barrels of the gun. On the basis of many simulation experiments, it was corrected bottlenecks of the current manufacturing line. Solution consists in elimination of some machines in the selected workplaces. For other workplaces, it was suggested to reduce eventually to increase the number of shifts of the operation. All the suggestions result not only in increase of manufacture production (in our case not less than 1000 pieces a day) but also in savings of labour and energies.

\section{REFERENCES}

Banks, J. 1998. "Handbook of Simulation”. New York: John Wiley \& Sons, 849 p., ISBN: 978-0-471-13403-9.

Banks, J. et al. 2005. "Discrete-event system simulation". New Jersey: Prentice Hall, 608 p., ISBN: 0-13-144679-7.

\section{AUTHOR BIOGRAPHIES}

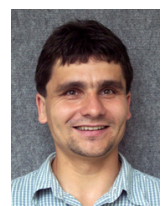

BRONISLAV CHRAMCOV was born in Uherské Hradiště, Czech Republic, in 1975. He studied Automatization and control technology at the Faculty of Technology in Zlín of the University of Technology in Brno, and he took his degree in 1998. In 2006 he graduated his doctoral degree from the Faculty of Applied Informatics of Thomas Bata University in Zlín. His doctoral thesis was focused on the utilization of time series prediction for control of technological process. He is working now as a lecturer at the Faculty of Applied Informatics of Thomas Bata University in Zlín. His research activities are focused on Control Algorithms for District Heating Systems, Time Series Forecast in Energy or Discrete event systems simulation. His email address is: chramcovefai,utb.cz.

LADISLAV DANÍČEK was born in Brod nad Dyjí, Czech Republic in 1983. He studied study program Information Technologies in study courses Engineering Informatics at the Faculty of Applied Informatics, Tomas Bata University in Zlín, and he took his degree in 2008. He solved problem of manufacturing line simulation within the frame of diploma work. Nowadays he is working as information manager on the Zlín Region. His email address is: ladislav.danicekekrzlinsky.cz. 